Historic, Archive Document

Do not assume content reflects current scientific knowledge, policies, or practices. 
Pleasure and Bean
from a

\section{WATER GARDEN}

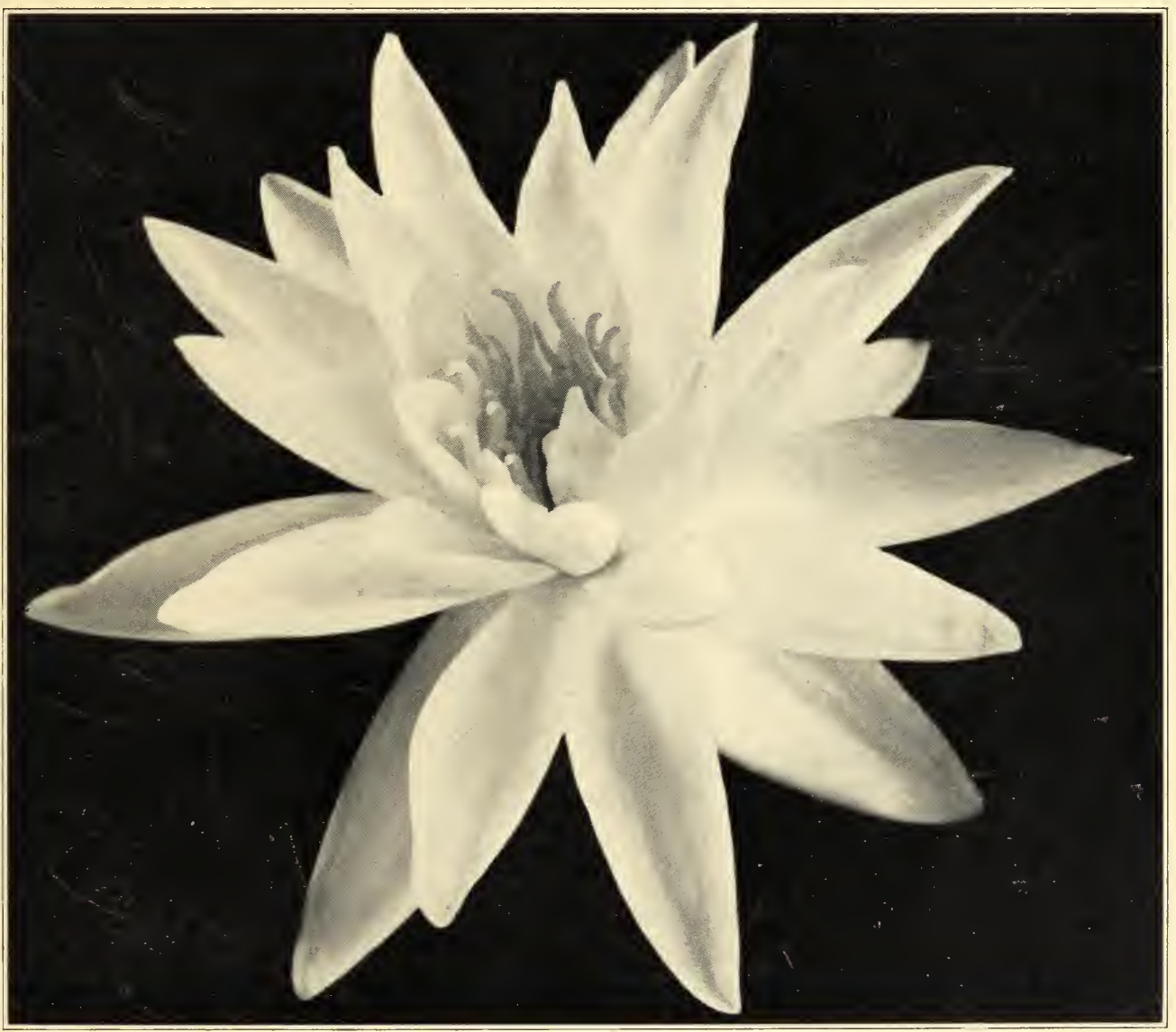

Descriptive Catalogue

\section{LOVELAND GOLDFISH FARM} JOE JOHANNIGMAN JR.

$$
\text { LOVELAND, OHIO }
$$




\section{THE METAL GARDEN POND}

Now you can have that garden pond you've always wanted. This pond permits you to install your own pool in an hour, and with a single tool-a spade. It is a permanent pond, temperature cannot effect it, it cannot crack, it will not rust. Why be without a garden pool any longer. Pick a sunny spot in your yard for it. Around the pool, perennials, and rock plants may be planted. No matter how small the garden, you can now find room to enjoy a water garden. Made in two sizes.

Length Width Depth Wgt. Price

No. 140 in. 36 in. 12 in. 120 lbs. $\$ 15.00$

No. 342 in. 40 in. 18 in. 198 lbs. $\$ 25.00$

No. 4.60 in. 48 in. 18 in. $\$ 35.00$

All prices F. O. B. our factory at Galion, O.
The Metal Garden Pond C O L L E C T I O N OF PLANTS, ETC., \$5.00. (Collection No. 1-A)

1 Water Lily - your choice of Pink Opal, Chrometella, A u ror a, Chrysantha, Blue Beauty.

6 Aquatic Plants-to be planted in pots and submerged.

12 Rock Plants or Hardy Perennials, your choice.

1 Pair Calico Fish.

6 Black Ramshorn Snails.

You may have your choice of any of the lilies listed on Pages 2 and 3 with the same plants, snails and fish offered in the above collection. Choose your lily and add $\$ 3.50$ to price listed.
Note the sturdy metal construction. Heavy $1 / 8$ inch copper steel throughout. Size is $3 \mathrm{ft}$. by $3 \mathrm{ft}$. 4 in. by 18 inches deep. Fittings for overflow and inlet pipe if desired.

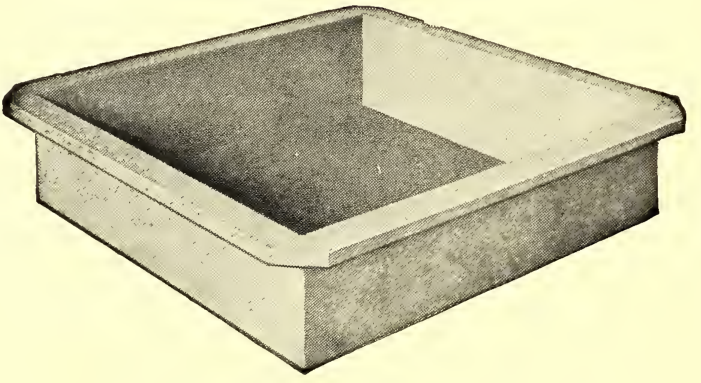

THE TUB GARDEN
With ordinary care this Metal Art Garden Pond will last indefinitely. It will also prove to be the most beautiful and most interesting spot in your garden.

The best effect will be gained by sinking the tub in the ground right up to the rim. Fill half full of rich soil, cover this with an inch of sand, fill with water and you are ready to plant.

Our complete tub garden $\$ \mathbf{5 . 0 0}$. Consists of : 1 Water Lily tub, $2 \mathrm{ft}$. diameter and 1 $\mathrm{ft}$. deep, made of white cedar.

1 Water Lily, your choice Pink, Opal, Chrometella, Aurora, or Blue Beauty.

6 Aquatic Plants, assorted floating and and bog plants.

6 Rock Plants.

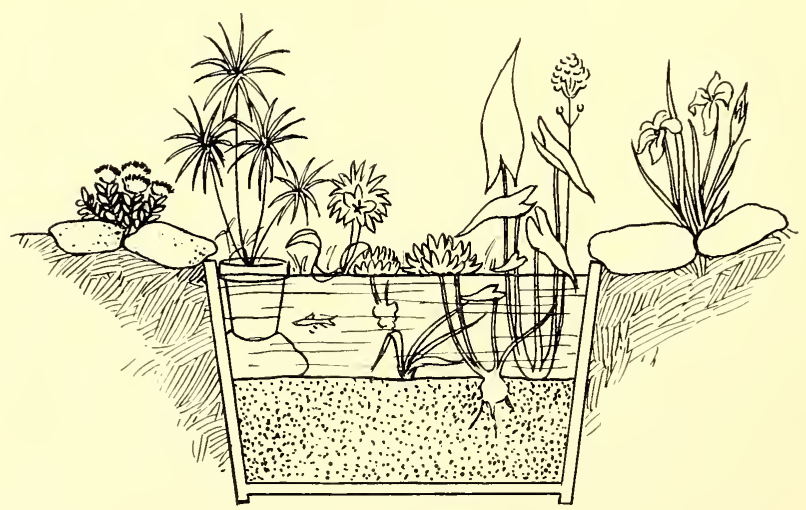

You can order extra tub if you like. They are used extensively in pools as soil containers in which to plant lilies and aquatics. These cedar tubs are strong and will last a long time. $\$ 2.50$ each. The collection may be ordered without the tub by deducting $\$ 2.00$ from the collection price. 


\section{HARDY WATER LILIES}

Hardy Lilies are unexcelled for planting in natural ponds concrete or rock pools or even in a half-barrel or tub. The flowers embrace all the colors, rich reds, beautiful whites, shell pinks to deep rose pinks, yellow and orange. Hardy Lilies are easy to grow, all you need is sunlight, water and rich soil.

\section{GENERAL LIST OF HARDY WATER LILIES}

Attraction-A wonderful deep red variety- $\$ 6.00$. Aurora-The flowers are rosy, yellow on the first day, red orange on the second and deep red on the third. One of the best for a small pool. $\$ 1.50$ each.

Carmine Ladyker-A pleasing carmine rose flower borne in rapid succession. $\$ 2.00$.

Chromatella-Rich yellow in color. Leaves beautifully marked in deep green and brown. It is by far the best of yellow varieties. $\$ 1.50$ each.

Chrysantha-An excellent new free blooming variety. Color undergoes a change on successive days, opening a creamy yellow and darkening until it is deep orange vermillion. \$2.50 each.

Comanche-A very large grower, free bloomer -blooms are very large, one of those varieties that the blooms change color-opening a rich apricot, then changing later to a deep bronze $-\$ 3.50$.

Eugenia de Land-Vigorous and free floweringdeep rose pink-\$1.50.

Hermine-A new glistening white variety that is in a class by itself. One of the best bloomers. $\$ 3.00$.

Gladstone-The boss of the white lilies, beautiful large white flowers, six inches across. A strong grower and a free bloomer. $\$ 1.50$ each.
Glorioso-This lily has no equal-it blooms and blooms. Its large blossoms are six inches across, of a remarkable red. No pool is complete without this "King of the Lilies." $\$ 4.00$ each.

Gonnere-The only real double white variety. Flowers are double clear to center. Visitors to our pools pronounce it the greatest lily of recent years. $\$ 7.50$ each.

Indiana-It opens a creamy yellow and shades through orange, bronze and fire red. Suitable for small pools, $\$ 2.50$.

James Brydon-Rosy crimson-cup shaped flowers - $\$ 2.50$.

Marliac Albida-Snowy white, with yellow stamens. A most desirable variety. $\$ 1.50$.

Marliac Rosea-One of the best lilies for cuttinga beautiful pink- $\$ 2.00$.

Mary-Small pink- $\$ 1.00$.

Paul Hariot-A splendid variety, canary yellow in color, shading into rich apricot as the flower grows older. $\$ 3.00$.

Pink Opal-This is a new variety. Its color is a deep, rich pink. $\$ 2.00$ each.

Rose Arey-Petals of this variety are pointed. The flowers a deep pink-a rapid grower. $\$ 2.50$ each.

Sioux-Large flowers of rich, brassy yellow, shaded red-\$2.50.

Solfatare-One of the best of the so-called "Sunset Lilies," broad cup shaped flnwers. One of the finest bloomers yet introduced. $\$ 3.00$.

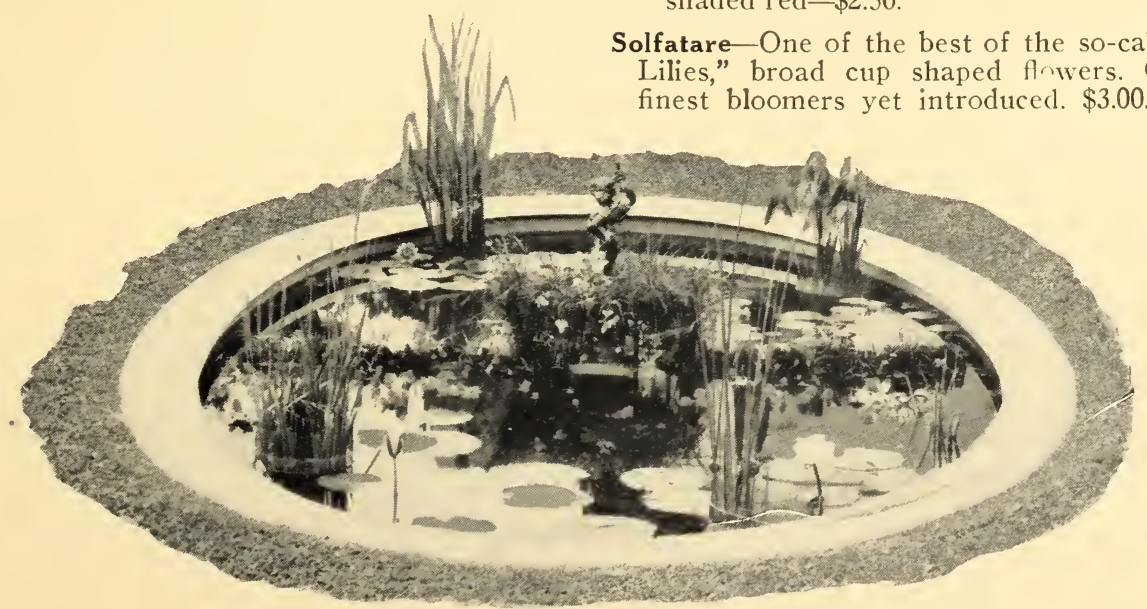

This Beautiful Pool from the Garden of H. R. Priest, Loudonville, O. 


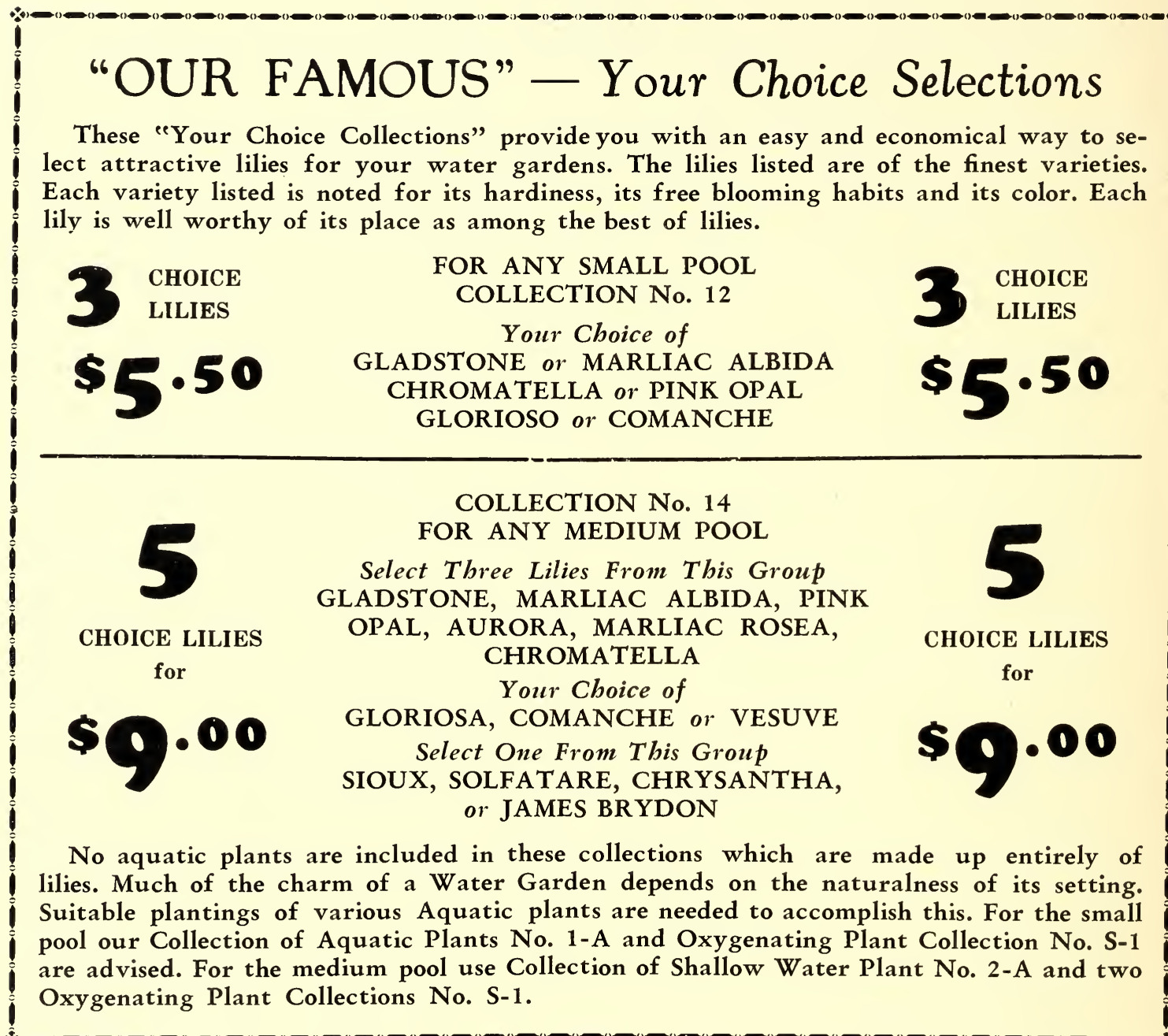

\section{THE SACRED LOTUS}

In planning your Water Garden, do not overlook making preparations somewhere for one of the Lotus. A unique and beautiful plant-there is real beauty in the leaf, the bud and the opened flower.

In planting the rhizoms settle them gently into the soil with the growing end just below the surface. They grow well in water, 2 inches to 12 inches deep and require the same general care as water lilies. A box for the Lotus should contain at least two cubic feet of good rich soil.

NOTE-Lotus are shipped about the first of June.

American Lotus (Nelubium Luten)-Yellow- $\$ 2$.

Chinese Red Lotus (Pekinensis Rubrum) Deep pink- $\$ 3.50$.
Egyptian Lotus (Speciosum)-An excellent variety, light pink- $\$ 2$.

Japanese Lotus (Album Grandiflorum) - A splendid white Lotus of gorgeous beauty. $\$ 2$. 


\section{TROPICAL WATER LILIES}

Tender Water Lilies give best results when planted after warm settled weather is assured. This is usually about June 1. Tender Lilies are free blooming. Tender Lilies are divided into two classes-the Day-blooming and the Night-blooming. Every pool should have its share of these beautiful Lilies.

\section{DAY BLOOMING TROPICAL WATER LILIES}

August Koch-This lily is free flowering and of extremely easy cultivation. Its flowers are 7 to 8 inches across, very fragrant. The sepals are purplish lilac and the petals pale wistaria violet. Strong and attractive foliage. \$2.50.

Blue Beauty-Deep blue flowers. Free and continuous flowering. Leaves and buds spotted with purple. $\$ 2.50$.

Dauben-It produces small, light blue flowers in great profusion. Fine for tub or aquarium. $\$ 1.25$.

General Pershing-Clear, distinct pink. The flowers are of great substance, delightfully fragrant. Opens early in the morning. $\$ 4.50$ each.
Mrs. C. W. Ward-A most charming variety with petals of rich rose-pink. Flowers are borne well out of the water. $\$ 2.00$.

Mrs. Geo. H. Pring-A new and novel type that produces numbers of large, fragrant, white flowers with pointed petals. Petals broader at the base and more pointed at the tip. $\$ 2.00$.

Mrs. Woodrow Wilson-This variety has lavenderblue flowers of large size. It is an extremely satisfactory day blooming variety, $\$ 2.00$.

Panama Pacific-It is an exerblooming, viviparous, strong growing and free flowering. The predominant color is reddish purple and the stamens are yellow. A most excellent variety. $\$ 2.50$.

\section{NIGHT BLOOMING TROPICAL WATER LILIES}

Bisset-A night bloomer of unusually free-blooming habit. The flowers are of a beautiful rose pink color, the petals are broad and slightly conclave giving the bloom a cup-shaped form. $\$ 1.50$ each.

Frank Trelease-Flowers a brilliant crimson. The most popular lily of its type because of its rich color. $\$ 2.00$.
Juno-Very large, beautiful snow white flowers, with a center of pure yellow stamens and produced freely. $\$ 2.50$.

Omarana-A pleasing pink lily. A vigorous grower and one of the freest flowering. \$1.50.

Rubra Rosea-One of the best. Brilliant rosy carmine flowers are held well above the glossy foliage. $\$ 1.50$ each.

\section{TRY THESE HARDY WATER LILIES FOR A DELIGHTFUL CHANGE}

These new Water Lilies merit their position of honor as the leader of the leading lilies of recent introduction.

Neptune-During the past summer, visitors to our place have agreed that it does not seem possible for a plant to flower any more freely. The most striking feature of this flower is the colorimagine a deep pink flushed with smoky red at the base, the tips of the petals becoming lighter. $\$ 5.00$ each.

Sunrise-It has enormous flowers attaining in size eight or nine inches. Its large glorious yellow blooms open early in the day. The leaves are large, deep green and red flecked. Unusual in form, beauty and fragrance. You will have to see this lily. \$5.00 each.

\section{LETTERS FROM WATER GARDENERS}

You can book my order for one each Mrs. Pring, Aug. Koch, and Frank Trelasse, to be delivered every spring until further notice. I have enjoyed the blooms of these lilies immensely. Nothing else in our gardens is so interesting and admired as our lily pool.-Joseph Stermer, Cincinnati, Ohio.
The water lilies which you delivered are all growing beautifully and have made our pond a real show place. All the lilies are blooming regularly. There is one more lily I want and that is Sunrise. I saw it in bloom when I visited your gardens early last spring.-John Stoner, Cincinnati, Ohio. 


\section{GOLD FISH-THE IDEAL POOL FISH}

No pool-even if it is a miniature one-is complete without a few ornamental fishes. Fish in the pool will take care of themselves, all is needed is an occasional feeding of Dried Shrimp or Lo-Co about once a day.

The illustrations show several different types. The illustrations are not exaggerated as is the case in other catalogues. You will be pleased with our selections.

Goldfish may be wintered outside in your pool, provided you have some soil and plants in it, and the depth is at least eighteen inches. If you drain your pool a tub or tank in the basement will answer.

Remember our stock of Goldfish is only complete during April to June and then from September to January. During the summer months we always have some fish on hand, but cannot promise certain sizes or varieties.

\section{THE BIG ONES}

Giant Goldfish -10 to 12 inches. $\$ 5.00$ per pair. $\$ 25.00$ per dozen.

8 to 10 inches, $\$ 2.50$ per pair. $\$ 12.00$ per dozen.

Giant Comets-The fish with that long wavy tail, 12 inches. $\$ 6.00$ per pair.

Large Orioles-An orange and black color. 4 to 6 inches. $\$ 1.50$ per pair.

Giant Pearls-6 to 8 inches. $\$ 2.00$ per pair. 10 to 12 inches, $\$ 6.00$ per pair.

Giant Shubunkins-The large size of the Calico Fish. 7 to 9 inches. $\$ 4.00$ per pair.

\section{COMET TAILS}

A variety with unusually long tails. Six to seven inches, $\$ 1.50$ per pair. $\$ 7.50$ dozen. 7 to 8 inches, $\$ 2.00$ per pair. 8 to 9 inches, $\$ 3.00$ per pair.

\section{POOL GOLDFISH}

A selected group of goldfish suitable for all pools. An assortment of colors, gold, gold and white, pearl, gold and black. Assorted 2 to 4 inches, $\$ 1.50$ per dozen, 25 for $\$ 2.50 .4$ to 5 inches, $\$ 3.00$ per dozen, 25 for $\$ 5.00$. 5 to 6 inches, $\$ 5.00$ per dozen. 6 to 7 inches, $\$ 6.00$ per dozen.

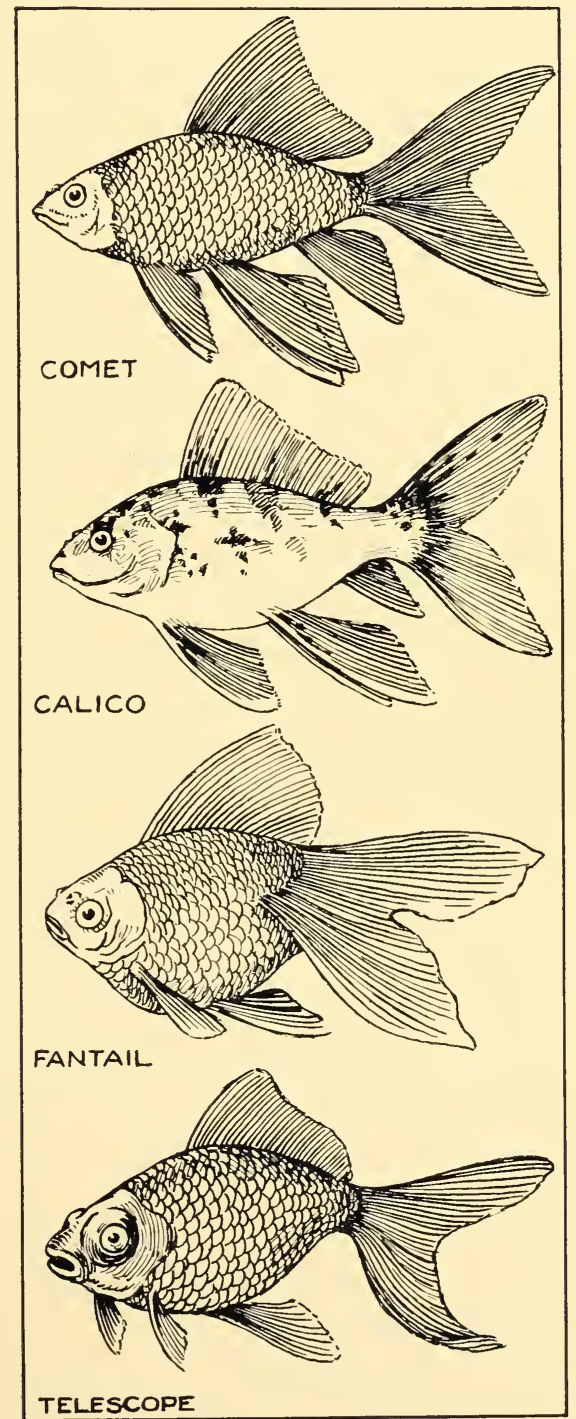

These are the best known of the fancy goldfish. 3 to 4 inches, $\$ 1.50$ per pair. 4 to 5 inches, $\$ 3.00$ per pair. 5 to 6 inches, $\$ 4.00$ per pair.

Giant Fantails $-\$ 3.00$ to $\$ 10.00$ each.

\section{TELESCOPES}

An odd fish with large protruding eyes. These fish are highly prized. Red and velvety black. Small sizes, $75 \mathrm{c}$ each. Medium, \$1.50. Large, $\$ 3.00$ each. It is very difficult to classify these fish according to inches. They are priced more according to quality.

\section{CALICO}

The wonder fish, marvelously colored, brilliantly mottled, blue, red, gold, brown, white yellow and black. A thoroughly hardy fish. No two fish are colored alike. 2 to 3 inches, $\$ 2.00$ per dozen. 4 to 5 inches, $\$ 1.50$ per pair. $\$ 6.00$ per dozen. 5 to 6 inches, $\$ 3.00$ per pair, $\$ 12.00$ per dozen.

\section{SHIPPING INSTRUCTIONS}

Goldfish are shipped by express. Customer to pay the charges. On small orders include 50c for shipping can, same is then your property. On large orders we loan you the can, same to be returned at once by express prepaid. The expess company make a flat charge of 20c for returning empty cans. 



\section{POPULAR COLLECTIONS Of WATER LILIES, PLANTS and FISHES} Famous Water Lily Collections
POPULAR TRIO- $\$ 4.50$
(Collection No. 6)
ORIENTAL COMBINATION
Amus, Amer. or Egyptian.
Amlano, nite blooming lily.
2 l'apyrus, 3 Cattail, 2 Umbrella,
2 Arrowhead Plants.
POPULAR FIVE- $\$ 10.00$
Collection No.
Lotus, Amer or Egyutian.
Cilromatella, yellow.
l'ink Opal, pulk.
Ml:arliac Allida, white
Chrysantha, orange.
Gilurioso, red.
DE LUXE FIVE- $\$ 15.00$ (Collection No. 9)
Sulfiatarre, clangeable.
lindiana, oringe.
Aliraction, deep red
Hermine, white.
Ruse Arey, deep rose

('hromatella, yellow.

Pink Opal, deep pink.
Marc Albida, white.

COMPLETE POO COLLECTIONS

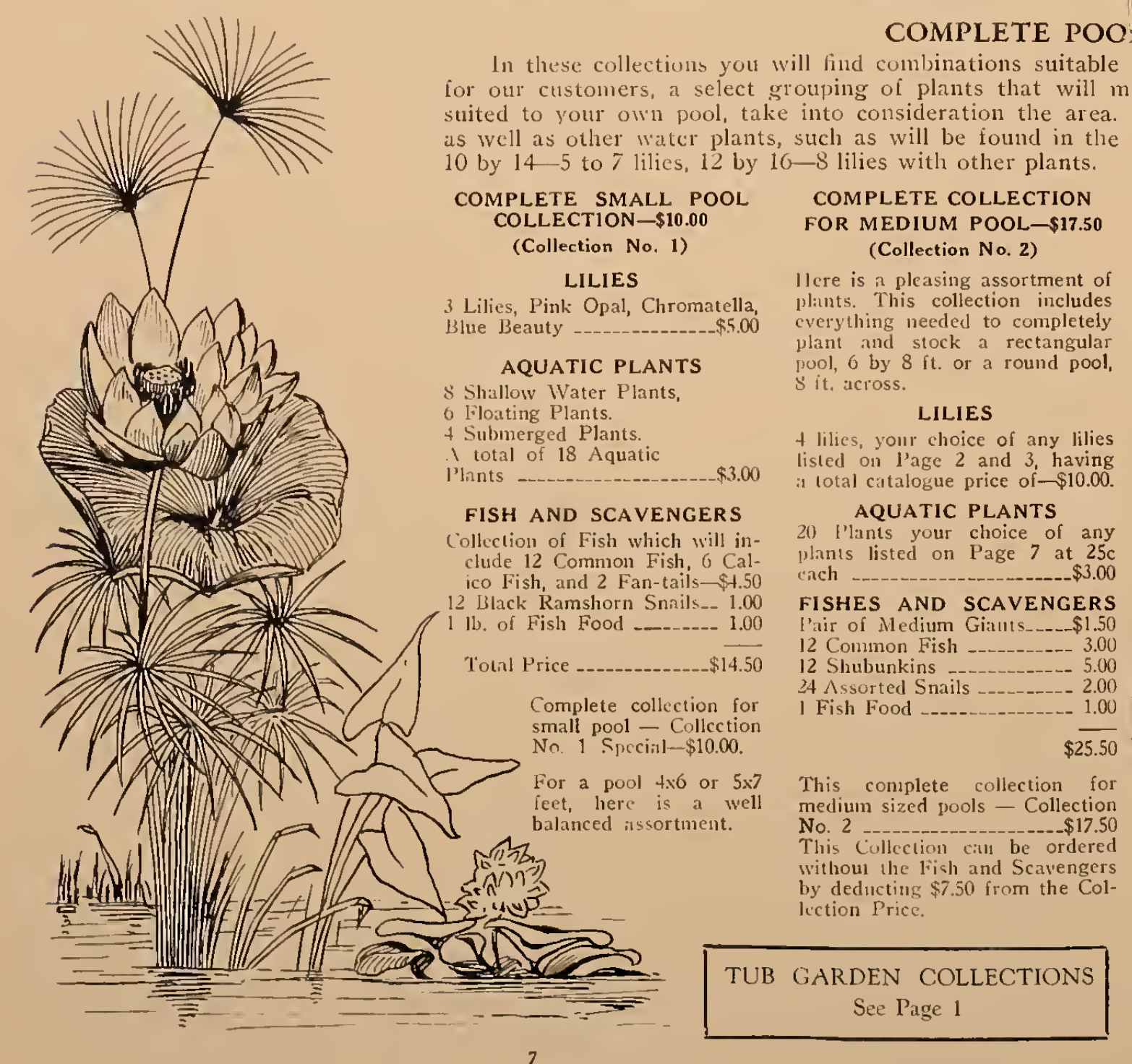

tutable for inly pool, large or small. We have endeavored to provide

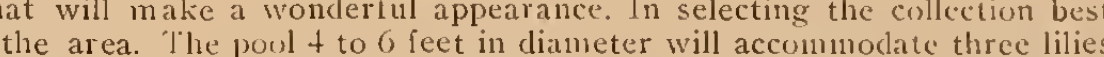
tound in the

OMPLETE SMALL POOL COMPLETE COLLECTION

Lilies, Pink Opal, Chromatella aQuATIC PLANTS Shallow Water Plants,

Sulting Plants.

ISH AND SCAVENGERS

(ollection of Fish which will in

clude 12 Common Fish, 6 Cal

ib. of Fish Food - - ----- 1.00

Complete collection for No. 1 Speciill- $\$ 10.00$.

COMPLETE COLLECTION FOR THE DE LUXE POOL

$$
\text { (10 by } 15 \text { or }
$$

(Coy 15 or larger)

$\mathrm{Ve}$ will provide for you a guide for the proper arrangements of phants for these collections, it lrief description of your por as to size, locntion, etc.

8 Lilies, this De Luxe is sortment each one "The Best" in color. Glorioso, red; Hermine, white;
Aug. Koch, blue; Solfatarre Aug. Koch, blue; Soliatarre,
clangeable; Comanche, orange:
Chrometella, yellow; Friulk Trelasse, night blooming; l'ink Opal, pink; catalogue value $\$ 28.00$ 1 Chinese Red Lotus -.20 Shallow Water und Biog

Plants -
Pr. Giant Goldfish --.-- 5.00 1 Pr. large Shubunkin ----- 2.00 50 Asst. Comnnon Fish ----- 7.50 6 Asst. Telescopes ------- 4.50 to 6 lilies and other plants,

COMPLETE COLLECTION FOR THE LARGE POOL (8 by $12 \mathrm{ft}$. or $12 \mathrm{ft}$ across)

(Collection No. 3) LILIES

5 Lilies your selection of lilies listed on Pages 2 and 3 having tolul catalogue value of $\ldots-\$ 15.00$
20 Aruatic Plants assorted
3.00 10 Submerged Plants Pr. Giant Goldfish (or young giant Golllish) -

12. Common Fis 24 Asst. Snail

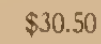

Everything you need. This collectiors of Plants, lissh, etc., for 6 Asst. Telescopes --.-- $\frac{4.50}{\$ 61.00}$

This complete collection for only $\$ 50.00$, or if you prefer to the fish deduct $\$ 25.00$ irom colection price.

Ayuutse Plint Collections See Page 8
SUNSET TRIO- $\$ 6.00$

(Collection No. 11)

Sulfitarre, chimgeable

Marora, orange.
Carmine Ladyker, red.

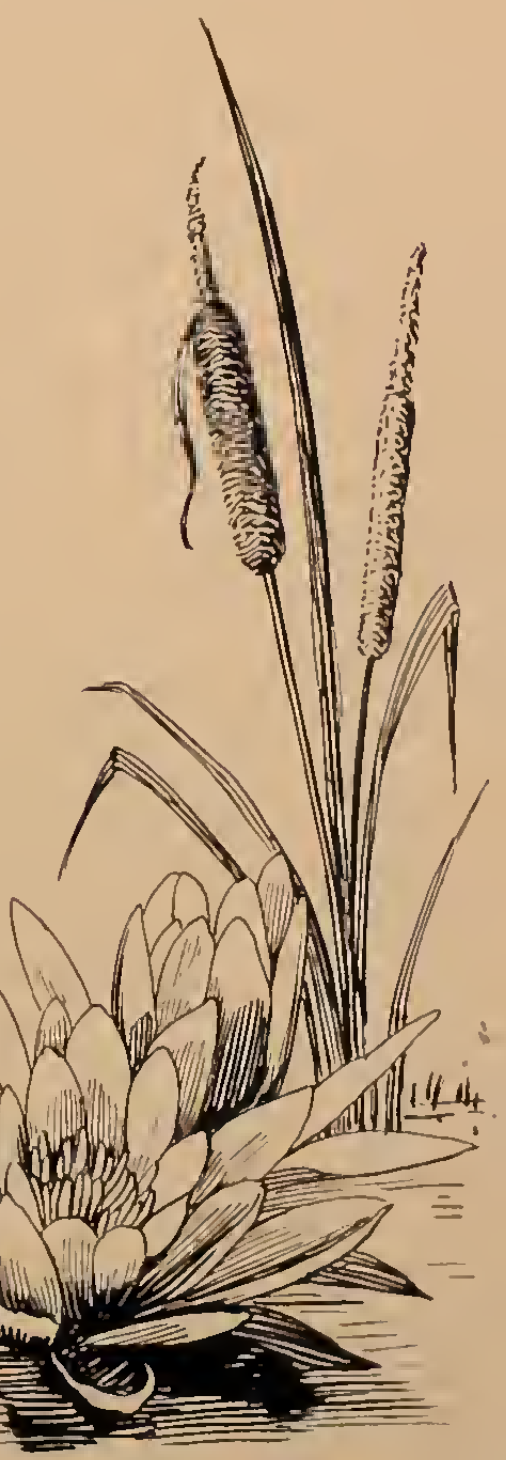




\section{WATER PLANTS FOR THE POND OR POOL}

Here are grouped those plants which grow in the water. They are varied and interesting, and give the much desired natural eff ect to the pool. They are easily grown. Most of them do best in shallow water and so the pots, boxes, or tubs should be raised to within 2 to 8 inches of the surface.

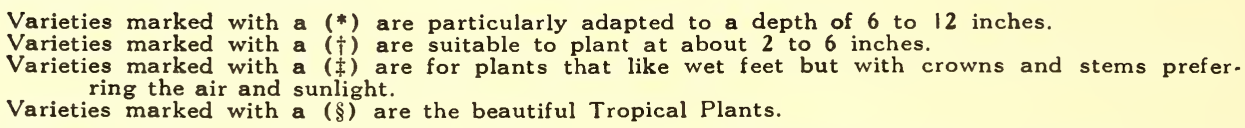

† Arrowhead, Giant-Beautiful shaped leaves, white flowers-3 for $50 \mathrm{c}$.

$\$$ Butterfly Lily-A tall canna-like plant with large leaves. White or yellow flowers-35c each, $\$ 1$ for 3 .

$\dagger$ Cat Tail-Swamp plant, hardy-\$1 per dozen.

$\dagger$ Graceful Cat-Tail-A tall variety with slender cat-tails. These plants furnish a very fine background in massed plantings. 25 cents each.

*Floating Heart-Small leaves resembling Water Lilies; brilliant yellow flowers-2 for $25 \mathrm{c}, \$ 1$ per dozen.

$\$$ Forget-me-not-The well-known spring and summer flowering plant-25c each, $\$ 2$ per dozen.

†Iris-(yellow flag) or (blue Versicolor). Very attractive and hardy $-25 \mathrm{c}$ each, $\$ 2$ per dozen.

+ $\uparrow$ Parrot Feather-Extremely valuable for trailing over a fountain - $25 \mathrm{c}$ a bunch.

$\S+$ Papyrus or Egyptian Paper Plant-A very beautiful water plant with plumy heads of foliage- $-35 \mathrm{c}$ each

${ }^{*}$ Primrose Creeper-A rapid growing, partially submerged aquatic, with yellow flowers-25c each, $\$ 2$ pe. dozen.

tPrimrose Willow-Erect plants 2 to 3 feet high, with attractive narrow foliage and bright yellow blossoms. Very desirable at the edge of pools or in a tub garden. 35 cents each. $\$ 2.50$ per dozen. $\dagger$ Pickeral Plant-Beautiful blue flowers. Total growth about 2 feet- $25 \mathrm{c}$ each, $\$ 2$ per dozen.

$\S \dagger$ Purple Water Hyacinth-A creeping plant, with handsome blooms-50c each.

$\S \dagger$ Thalia-A handsome canna-like aquatic standing 3 to 6 feet high- $50 \mathrm{c}$ each, 3 for $\$ 1.25$.

$\S \dagger$ Umbrella Palm-We have an excellent strain of this old-fashioned plant, produces large fan-like leaves-25c each, $\$ 2$ per dozen.

$\dagger$ Variegated Sweet Flag-One of the best of the shallow water plants; sabe. like leaves, broadly striped green and ivory-25c each, $\$ 2$ per dozen

$\S \dagger$ Water Poppy-Leaves float upon the water. Flowers are large and yellow. Should be in every pool-25c $\$ 1.50$ per dozen.

\$Water Hyacinth-A beautiful floating plant. Spikes of orchid-lavender flowers are produced freely if the roots are allowed to anchor in soil2 for 25 c, $\$ 1$ per dozen.

$\S$ Water Fern-An aquatic fern producing small ferns on upper side of the leaves. 50 cents for 3 .

$\S$ Water Lettuce-A pretty floating plant with green fluted leaves and long wavy roots. 3 for 50 cents. $\$ 1.50$ per dozen.

*Water Snowflake-A lily like plant with dainty white flowers. 35 cents each.

\section{SUBMERGED PLANTS FOR THE POOL OR AQUARIUM}

These plants grow under water, they absorb the impurities or release oxygen to destroy them. These plants are indispensable when fish are present, as they provide a perfect balance for the animal life. They can be rooted in soil, or planted in the lily boxes.
Anarcharis

Cabomba

Money Worth

Myriophyllum

\author{
Ludwigia \\ Sagittaria \\ Southern Spatterdock \\ Vallisneria
}

COLLECTION OF SUBMERGED PLANTS

For Small Pool-10 Plants........\$1.00 


\section{COMPLETE AQUATIC PLANT COLLECTIONS \\ SMALL POOL COLLECTION-\$3.00 \\ (Collection No. 1-A) \\ MEDIUM SIZE POOL- $\$ 4.00$ \\ (Collection No. 2-A) \\ This group includes 12 plants for shallow 12 shallow water or bog plants. \\ water planting, 4 oxygenating plants, 4 oxygenating plants. \\ 4 floating plants. \\ 12 floating plants.}

Collection No. 3-A) of 7 Bog or Marsh Plans, $\$ 1.50$

Collection (No. 4-A) of 7 Shallow Water Plants, $\$ 1.00$

Collection (No. 5-A) of 7 Floating Plants, $\$ 1.00$

These collections are suitable for use in pools, where at least one to five lilies may be grown. The small collection for pools $4 \times 6$ feet. Medium collection for pools $6 \times 10$.

\section{SCAVENGERS FOR POOL AND AQUARIUM}

Natural scavengers are essential for cleanliness in the garden pool or the balanced aquarium. They help prevent the excessive growth of algae and devour decaying vegetation, as well as consuming excess food.

African Snails - Hardy brown shelled, mottled with dark spots. $\$ 1.00$ per dozen.

Japanese Snail-These snails help to keep the water clear. Large and hardy. $\$ 1.50$ per dozen, $\$ 10$ per 100 .

Coral Snails-The beautiful Red Ramshorn snail. 25c each, $\$ 2$ per dozen.

Australian Red Snails-Color a bright red. 50 cents for two.

Black Ramshorn Snails-Very prolific egg layers and very useful in removing the algae or green scum. 50c per dozen, $\$ 3$ per 100.

Trumpet Snails-Hardy prolific scavengers. 75 cents per dozen.

Japanese Water Babies-A handsome variety. Red and Black. Good insecteaters. 2 for 50 c, $\$ 2.50$ per dozen.
American Water Babies-A $\mathrm{h}$ a r m le s s species of water newts. Golden brown with red lines and black dots on the back. 2 for 25 c, $\$ 1.50$ per dozen.

Green Frogs-How about a pair of our "Caruso' s" to sing to you at night. $75 \mathrm{c}$ per pair, \$3 per dozen.

Clams and Water Mussels-Use plenty of them in the pool. They help keep the water clear. $\$ 1.50$ per dozen.

Weather Fish-A curious eel-like fish. 4 to 6 inches long. \$1 per pair.

Baby Alligators-Have Miami in your back yard. \$2 each.

Geographic Turtles-Little fellows, two inches across, with curious markings in both upper and lower shells. More ornamental than useful. 25c each, $\$ 2.50$ per dozen.

\section{COLLECTION OF SCAVENGERS \\ For the Small Pool \\ Collection No. S-2 \\ For the Medium Pool \\ Collection No. S-3}

For the average small pool a general assortment of 24 scavengers including Japanese, Black Ramsborn, African and Trumpet Snails, Clams, etc., including shipping can, $\$ \mathbf{1 . 5 0}$.
For the average medium pool, a novelty collection of 30 scavengers including Snails, Turtles, Salamanders and Clams, including shipping can, $\mathbf{\$ 2 . 5 0}$. 


\section{WATER I R IS AND OTHER FLOWER PLANTS FOR EDGING THE POOL AND FOR BACKGROUND}

\section{Japanese Iris}

These beautiful Iris thrive in moist soil around the pool as well as in your garden.

Gold Bound-Double, pure white. Iphigenie-Deep chinese lilac.

Mahogany-Mahogany red, double.
Purple and Gold-Rich purple.

Moniji-no taki-Bright rose.

Prosperpine-Single, bright rich blue.

\section{Collection (No. P-1) 6 large size clumps for $\$ 2.00$}

\section{Siberian Iris}

The flowers resembling the Spanish and English Iris. They make a bright show in the garden and are excellent for cutting.

Snow Queen--Pure white.

Blue King-Deep Purple.
Snow Flake-Tall graceful, pale blue. Grandis-Light blue and white, tall.

Emperor-Dark violet blue, large bloom.

Collection (No. P-2) 5 generous size plants, $\$ 1.00$

\section{ORNAMENTAL GRASSES}

To give the real Tropical appearance to your Water Garden your first thought should be a collection of the beautiful hardy ornamental grasses.

Zebra Grass

Stripped Eulalia

\section{Outstanding Perennial Flower Plants}

Artemisia-Silver King

Astilbes-Pink

Aquiligias-Columbine.

Coreoposis-Yellow

Dianthus-Scarlet Beauty

Elder Daisy

Delphinium-English Hybrids

Gaillardia-Blanket flower

Hibicus-Giant flowers

Liatris-Very showy plant

Brilliant carmine rose flowers

on a magnificent spike

Lobelia-Blue

Lupinus-Regal

Phlox-Jules Sandeau

Tritoma-Red Hot Poker

Veronica-Speedwell

Yellow Day Lilies

Longifolia

Flava

Kwanso

Minor

Thumbergi

Yucca Filamentosa

SINGLE VARIETIES

$25 \mathrm{c}$ each, $\$ 2.00$ per dozen

\section{COLLECTION OF ORNAMENTAL GRASSES}

6 Plants for $\$ 1.50-12$ Plants for $\$ 2.50$

Ribbon Grass

Stripped Oat Grass

\section{Plants for Growing Among} Rocks

Achillea-Boule de Neige

Alyssum rostratum

Aster-Mauve Cushion

Arabis alpina

Aubretia-Wall cress

Dianthus-Deltoides

Festuca-glauca

Hens and Chickens

Oenothera-Evening Primrose

Myosotes-Alpestris

(Forget-me-not)

Nepeta mussini

Phlox subulato

Sedum

Acre

Altenum

Brilliant

Iborium

Kamtschaticum

Spectabile

Stahlii

Thymus vulgaris

Veronica in varieties

Violas

SINGLE VARIETIES

25 c each, $\$ 2.50$ per dozen 


\section{FISH FOODS and SUPPLIES}

Dried Shrimp-Excellent for either goldfish or tropical fish. Small tins, 20 cents; $\$ 1.00$ per $1 \mathrm{~b}$.

Lo-Co-A prepared cereal and meat food. This type of fish food is very popular. It is easy to use. $\$ 1.00$ per $1 \mathrm{~b}$.

Regular Fish Food-An economical food where one has a large number of goldfish. Per large carton, 50 cents.

Besco Fish Food-For aquarium use. Small tins, 15 cents.

Turtle Food-A prepared food for these curious little pets. They will also eat raw meat. Tins, 25 cents.

Sea Salt-Salt is a preventive of disease. Should be used for all minor ills of goldfish. Use two tablespoons per gallon and leave fish in bath for several days. Per large carton, 50 cents.

Our Own Fungus Remedy-Three to four drops will help cure most external diseases of fish. It is advisable to use as an antiseptic before introducing new fish to the pool or aquarium. Per bottle, 50 cents.

Water Lily Tubs-Galvanized. $\$ 1.00$ each.

\section{We Are At Your Service}

Your success in making a water garden or establishing an aquarium depends on your first advice. We are always ready to advise regarding choice of varieties of Waterlilies and Water-Plants, general cultural methods and in fact, any matter concerning the making of the water-garden and will answer all questions. Please feel free to write us.

WE ARE AT YOUR SERVICE.
Permanganate Crystals-A disinfectant. Used in a solution tinting water a faint pink color. Helps destroy algae in the pool. Use with discretion. 50 cents.

Red Wood Boxes-For planting Water Lilies. These boxes hold about one cubic foot of earth. Will last a long time. Come knocked down or completed. 50 cents each.

White Cedar Tubs-Excellent for use in planting Lilies or the Lotus. $\$ 2.50$ each.

Fish Nets-Small for aquariums. 15 and 25 cents.

Fish Net Handles-Square aluminum nets. The ideal net for tropical fish. Comes without the netting. 35 cents each.

Glass Dip Tubes-For removing sediment. 60 cents for $14 \mathrm{in.} 75$ cents for $18 \mathrm{in.}$

Glass Aquarium Syphons. 75 cents each.

Aquarium Cement. Per carton, $\$ 1.00$.

Fertilizer or Water Garden Plant Food. A good fertilizer, use 1 quart per bushl of clay soil or 1 quart for 2 bushels of good garden soil. 5-1b. sacks, 75 cents. Quart carton, 30 cents.

\section{Goldfish Dip Nets}

No. N-1-The net has $1 / 4$-in. sq. mesh in the bottom, $3 / 8$-in. sq. mesh in the top, with a 12-inch round ring with $6 \mathrm{ft}$. plain wooden handle. Each

No. N-2-Same net as above except with a 12 -inch $D$ shaped ring. Nets 18 inch deep. Each

\section{LOUSE REMEDY}

A new German remedy to rid fish of this pest. Box $\$ .50$

Perhaps you have friends who would enjoy learning about my Water Gardens. Send me their names and addresses and I will mail them one of my catalogues. 


\section{TROPICAL FISH-FOR THE AQUARIUMS}

This is our first season in listing these beautiful and fascinating fish. Our collection at present is small and we hope to add in the future, more varieties until our list is complete. You can enjoy these fish in a small aquarium in your own home. They are small, and many can be placed in an ordinary aquarium.

Blue Moons-The male usually has red markings on the dorsal fin and sometimes on the body. Three-quarters to an inch and a half long. $\$ 2.00$ per pair.

Black Moons-A striking jet black. $\$ 2.00$ per pair.

Red Moons- Gold Moons-\$2.00 per pair.

Mexican Swordtails-The most popular of tropical fish. Green Sword. Young are born in lots of twenty or more. $\$ 1.50$ and $\$ 2.00$ per pair.

Paradise Fish-This fish will stand temperature as low as 40 degrees Fahr. 2 to 3 inches. $\$ 1.50$ to $\$ 3.00$ per pair.
Sailfins-The largest and hardiest live-bearing fish. The male has an immense dorsal fin. The fins and tail gleam with shades of green and blue. $\$ 2.00$ per pair.

Rainbow, Peacock, Fish or Guppyi-The best known of the live-bearing fish. The male is less than an inch long. The female larger. 50c per pair.

All shipments on Tropical Fish are made by Express Collect. They are shipped in cans from June 1 to October 1, but during the other months, it is best to use insulated cans.

\section{AQUARIUMS-The Beauty Spot of the Home}

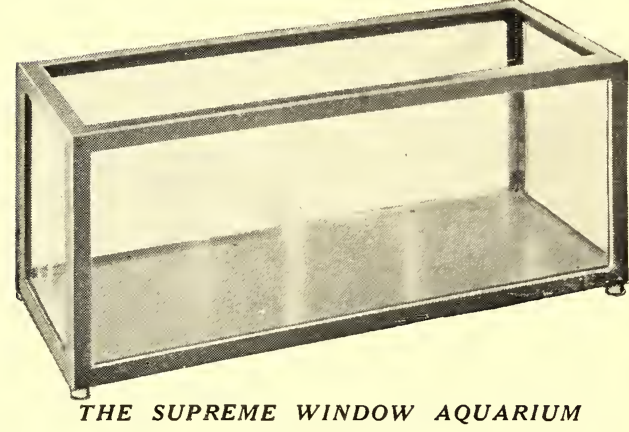

The Window Seat Aquarium-A type that is becoming very popular as it may be used in a window seat, narrow shelf or small table. Heavy slate base. Green enamel finish.

INo. $1-30$ by 8 by $10 \mathrm{r} / 2$ inches, 8 gallon. $\$ 11.00$.

The Supreme Window Aquarium-This aquarium is constructed out of heavy angle iïon, double strength glass. Glass bottom. Finish dark green Will last a long time.

No. 2-24 by 12 by 12,12 gallons. $\$ 16.00$.

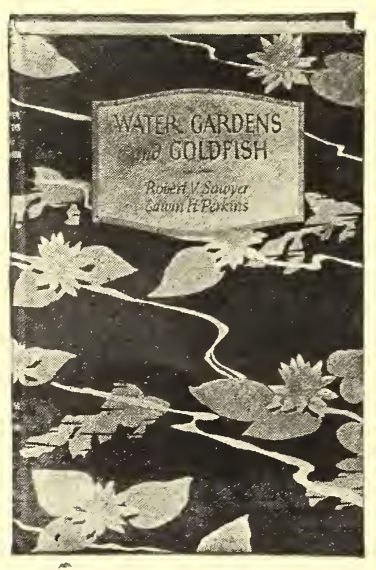

\section{BOOKS-on Goldfish and Water Lilies}

MODERN AQUARIUM, by W. T. Innes. A new book covering the breeding and general care of goldfishes and tropical fishes. 64 pages and 30 illustrations. $\$ 1.00$ per copy.

THE WATER GARDEN, by Peter Bisset, is an excellent work dealing with the culture of water lilies and other aquatic plants. 210 pages. $\$ 5.00$ per copy, postpaid.

WATER GARDENS AND GOLDFISH, by R. V. Sawyer and E. Perkins. A new book covering the Water Garden; also dealing with the general care of goldfishes. 112 pages, 59 illustrations. $\$ 1.65$ postpaid. 


\section{Have You Overlooked Anything in Ordering?}

The Tub Garden

Don't pass up another year without having the pleasure of a Water Garden. Begin with either our Complete Tub Garden or a Metal Art Garden Pool. Both listed on page 1.

\section{Water Lilies}

Read over the list of Hardy Lilies on page 2 and the beautiful Tropical Lilies on page 4. Our "Your Choice" collections on page 3 is well worth the money. The Ideal Collection of thirty plants listed on page 5 together with diagram of planting should not be overlooked. Then on page 7 and 8 are the Popular Collections of Water Lilies and other Water Plants.

\section{Lotus}

Make room somewhere in your pool for one of these stately and beautiful plants. See page 3 .

\section{Goldfish and Scavengers}

See page 6 and page 10 .

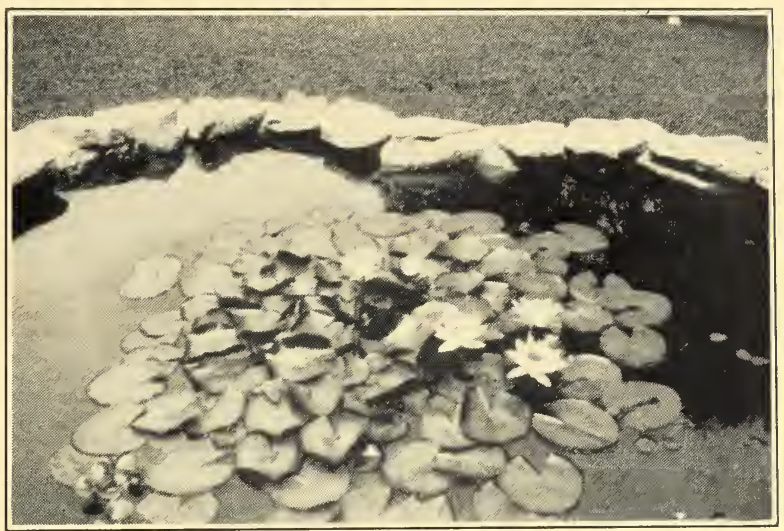

\section{Plants to Complete the Water Garden}

Floating, submerged, bog, and shallow-water plants. See page 9 and 10.

\section{Water Hyacinths}

You need these plants in the pool for the fish to spawn on. Hyacinths listed on page 9.

\section{Fish Foods}

The fish will get hungry. See page 12 .

\section{Dip Nets}

You will need one to catch the fish. Listed on page 12 .

Hardy Perennials and Rock Plants

For edging the border. Seepage 11.

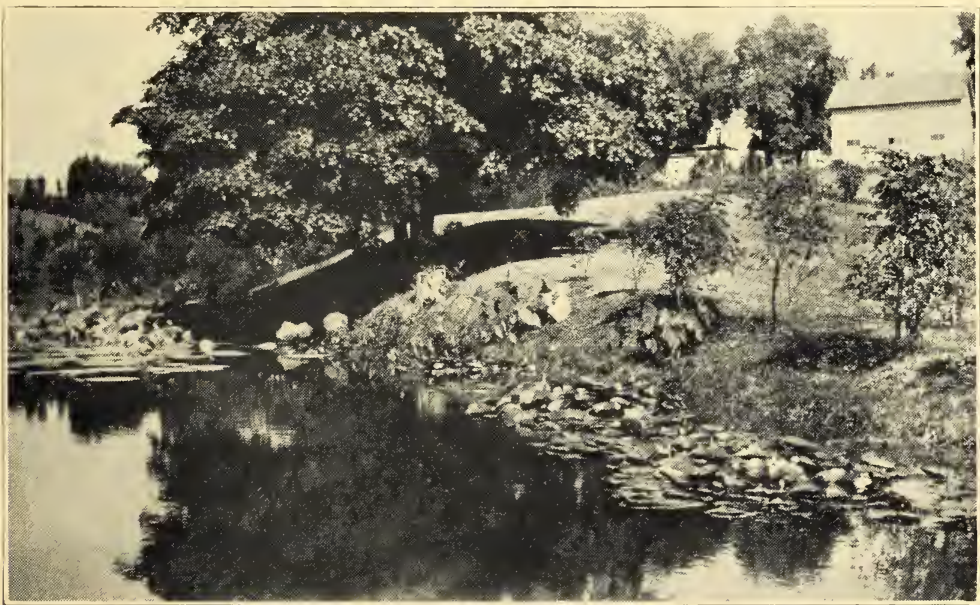

A natural pool in the gardens of Mr. Fromme Morris, Cincinnati, Ohio

\section{Water Garden} Fertilizers

See page 12 .

\section{Cultural Notes}

Folder enclosed with each order.

Order Instructions

See back page.

How to Reach Us By Machine

See back page. 


\section{HOW TO REACH US-JUST A PLEASANT DRIVE}

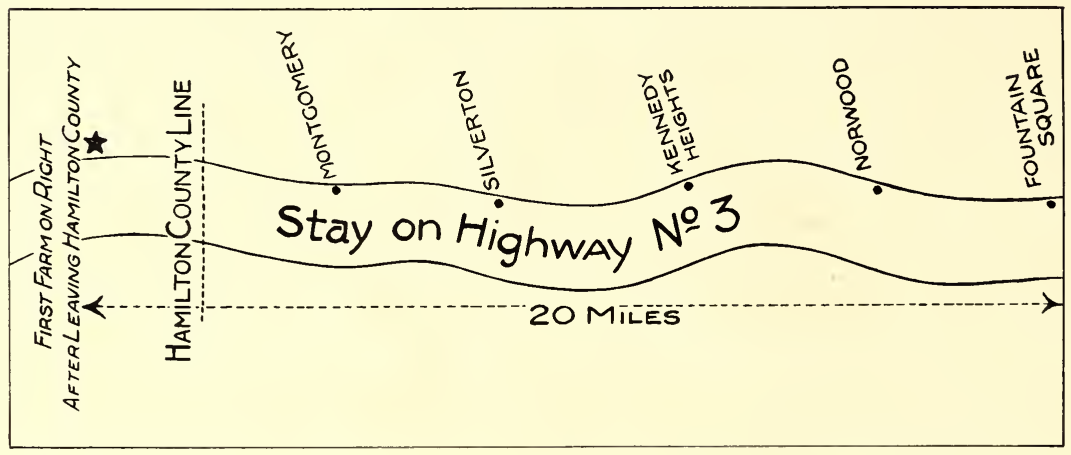

\section{ORDER INSTRUCTIONS}

ORDER EARLY-This is most important. Choice varieties invariably are exhausted and you will thus avoid substitution by early booking.

How and When We Ship-lris and Gladiolus are shipped Parcel Post prepaid. All other shipments are made by express collect, unless you instruct otherwise. Goldfish and supplies, and aquarium plants are shipped any time. Water Lilies, commencing May 1. Tropical Lilies, Lotus and Tropical Plants, June 1.

We ship good stock, carefully packed, but after shipment has left our hands we assume no responsibility whatever for delay, loss or damage in transit, nor for results after arrival.

Remittance must accompany all orders.

Send bank draft, express or postal money order or, if more convenient for you, send your personal check.

For Cincinnati Water Gardens-Anyone desiring our service to supervise, or plan, or plant their Water Gardens, should place such requests early, so that we can arrange our schedule of work.

How To Reach Us-We are located on the Montgomery Pike, which is State Highway No. 3, about twenty miles from Fountain Square, Cincinnati; first farm on the right after leaving Hamilton County line. (You do not have to go through Loveland, Ohio, to reach us.) Remember-we are right on the pike, State Road No. 3.

Perhaps you have friends who would enjoy learning about my Water Gardens. Send me their names and addresses and 1 will mail them one of my catalogues.

Cultural Directions-We have printed on small leaflets complete cultural directions. One of these will be sent with each order. 